\title{
Humanization of Care from the Perspective of the Family Health Strategy Teams in a City in the Interior of São Paulo, Brazil ${ }^{1}$
}

\author{
Maria José Sanches Marin ${ }^{2}$ \\ Luana Vergian Storniolo ${ }^{3}$ \\ Maria Yvette Moravcik ${ }^{4}$
}

\begin{abstract}
This study analyzes the understanding of professionals composing teams of the Family Health Strategy concerning humanization of care. This qualitative survey was carried out in a city in the interior of São Paulo through interviews with 20 professionals. The data analysis method used was Interpretation of Meanings based on the hermeneutic-dialectic perspective. The meaning of humanization according to the interviewed professionals includes an enlarged view, respect for ethical principles and facilitated access. The difficulties refer to the lack of prepared professionals, excessive demand and deficiencies in service organization. The professionals propose to educate and qualify professionals, make activities adequate given the professionals' roles and improve the organization of services. The professionals demonstrate understanding of the meaning of humanization and acknowledge the need to cope with difficulties.
\end{abstract}

Descriptors: Humanization of Assistance; Patient Care Team; Family Health.

\footnotetext{
${ }^{1}$ Paper extrated from research project, scientific initiation (modality Brazilian research). Supported by Fundação de Apoio à Pesquisa do Estado de São Paulo (FAPESP), process \# 2008/55576.

${ }^{2}$ RN, Post-doctorado fellow, Universidade Federal de São Paulo, SP, Brazil. Professor, Faculdade de Medicina de Marília, SP, Brazil. E-mail: marnadia@terra.com.br.

${ }^{3}$ Undergraduate Student in Medicine, Faculdade de Medicina de Marília, SP, Brazil. FAPESP Scholarship holder (modality scientific initiation). E-mail: luanastorniolo@hotmail.com.

${ }^{4}$ Physician, Specialist in Dermatology, Faculdade de Medicina de Marília, SP, Brazil. E-mail: somebody@terra.com.br.
}

Corresponding Author:

Maria José Sanches Marin Faculdade de Medicina de Marília

Rua: Monte Carmelo, 800

Bairro Fragata

CEP: 17500-000 Marília, SP, Brasil

E-mail: marnadia@terra.com.br 


\title{
A humanização do cuidado na ótica das equipes da estratégia de saúde da família de um município do interior paulista, Brasil
}

Este estudo teve como objetivo analisar a compreensão referente à humanização do cuidado, sob a ótica de profissionais que compõem as equipes da Estratégia de Saúde da Família. Trata-se de estudo qualitativo, realizado em um município do interior paulista, a partir de entrevistas com 20 profissionais. Na análise dos dados, foi utilizado o método de interpretação de sentidos, baseado na perspectiva hermenêutico-dialética. O significado da humanização, para os profissionais entrevistados, compreende olhar ampliado, respeito aos princípios éticos e facilitação ao acesso. As dificuldades se referem à falta de profissionais preparados, excessiva demanda e deficiências na organização do serviço. Eles apresentaram, como proposta, formar e qualificar profissionais, adequar as atividades ao papel profissional e melhorar a organização dos serviços. Os profissionais demonstram compreender o significado da humanização e reconhecem a necessidade de enfrentamento das dificuldades.

Descritores: Humanização da Assistência; Equipe de Assistência ao Paciente; Saúde da Família.

\section{La humanización del cuidado bajo la perspectiva de los equipos de la estrategia de salud de la familia en un municipio del interior paulista, Brasil}

\begin{abstract}
Este estudio tuvo como objetivo analizar la comprensión referente a la humanización del cuidado a partir de la perspectiva de profesionales que componen los equipos de la Estrategia de Salud de la Familia. Se trata de estudio cualitativo, realizado en un municipio del interior del estado de Sao Paulo, a partir de entrevistas con 20 profesionales. En el análisis de los datos fue utilizado el método de interpretación de los sentidos, basado en la perspectiva hermenéutica-dialéctica. El significado de la humanización para los profesionales entrevistados comprende una perspectiva ampliada, que incluye principios éticos y la facilidad para acceder al cuidado. Las dificultades se refieren a la falta de profesionales preparados, excesiva demanda y deficiencias en la organización del servicio. Los profesionales presentaron como propuesta formar y calificar profesionales, adecuar las actividades al papel profesional y mejorar la organización de los servicios. Los profesionales demuestran comprender el significado de la humanización y reconocen la necesidad de enfrentar las dificultades.
\end{abstract}

Descriptores: Humanización de la Atención; Grupo de Atención al Paciente; Salud de la Familia.

\section{Introduction}

In order to meet the health needs of the Brazilian population, the Brazilian Single Health System (SUS) has proposed changing the current health model, the characteristics of which are fragmented care centralized on disease and its biological and healing aspects. The proposed changes are guided by the principles of care integrality ${ }^{*}$, universality of access, political/administrative decentralization, equity and the incorporation of new technologies, knowledge and practices ${ }^{(1)}$.

Based on these principles, the Family Health Strategy (FHS) has been implemented since the 1990s as a way to re-orient health services through interventions in order

* Integrality refers to the idea that individuals are historical, social and political subjects and should be considered in their totality during the care delivery process. It also assumes that health care actions should be combined and focused on health promotion, prevention and healing. 
to address the needs, exposure and vulnerabilities to which individuals are subject, which enable professionals to acquire an enlarged view concerning the diseasehealth continuum and the need to implement actions beyond curative practices ${ }^{(2)}$. In light of this strategy, the following are elected as main points: the establishment of bonds, commitment and responsibility between health professionals and the population ${ }^{(1)}$.

The National Policy of Humanization (NPH) can be considered an axis, since it includes in its guidelines and priorities all the subjects involved in the health production process, proposing transformation in the social relationships among the involved actors. From the management perspective, it proposes the implementation of participative management and horizontal decision-making, teamwork, valorization and the participation of all the actors, sharing responsibility among managers, workers and users. In terms of care delivery, this policy targets accessibility and integrality of care, bonds between workers and the population as well as the advancement of an "enlarged clinic" dealing with the needs of individuals(3).

Moving in this direction represents a great challenge to the health system because it implies cultural changes in care delivery and in the management of work processes. To consider health as a value to be used is to ensure the rights of users and respective family members and to encourage social control, but also to provide better working conditions so that professionals work with dignity and thereby implement new actions and effectively participate as subjects of the work process $^{(4)}$.

Humanization initiatives will only be understood in their totality when health professionals perceive the value of their role in this context and believe in the human capacity to construct a better and fairer world. From this perspective, humanization of care requires the development of a critical consciousness of professionals as they search for the means to implement quality care(5).

We also highlight that health services are produced through the meeting between the one who produces the service and the one who receives it, that is, production is singular and occurs during the act itself. The production of health care, therefore, is based on an intense interpersonal relationship and depends on the establishment of bonds between those involved for it to be efficient ${ }^{(6)}$, which means health professionals need to be careful to listen, dialogue and maintain ethical and caring relationships. Hence, it is the role of health professionals to collaborate with a process in which individuals, families and communities are included in the health care process $^{(7)}$.

Counter-hegemonic concepts, guidelines and practices are observed in the context of primary health care and there are no actors prepared to comply with the proposed tasks ${ }^{(8)}$. Such facts lead to the constant challenge of searching for innovative strategies adequate for each context, which demands persistency and creativity in understanding and coping with the diverse and complex needs faced in the routine of providing health services.

Given the relevance of the humanization policy to the construction of a new care model, the challenge its implementation imposes on those involved in the process and the need to obtain information that can contribute to improved humanization conditions, this study analyzes the understanding of professionals from the FHS teams in a city in the interior of São Paulo, Brazil concerning care humanization.

\section{Method}

This qualitative study was carried out in a city with approximately 220,000 inhabitants. The FHS cares for about $40 \%$ of the population, has 29 units in areas of greater socioeconomic need and where the people of which, therefore, face increased difficulty in accessing health services. In general, the units meet the minimum requirements necessary to their implementation according to the Ministry of Health in regard to physical structure, minimum number of team members and the development of basic national programs.

For defining the sample, four Family Health Units (FHU) were randomly drawn, one in each region of the city (North, South, East and West). These units are referred to as 1, 2, 3 and 4 respectively. The following professionals from each unit were invited to participate in the study: Physician (P), Dentist (D), and Nurse $(\mathrm{N})$, in addition to one Nursing Auxiliary (NA) and one Community Health Agent (CHA), totaling 20 subjects.

Data collection was carried out in November and December 2008 through semi-structured interviews , which were recorded on a digital recorder and later transcribed by an experienced individual.

Interviews were based on the following principles of qualitative sampling: (a) to choose the subjects who have the attributes related to the intended topic of study; (b) to consider such subjects in sufficient number so that there is recurrent information; (c) to consider the possibility of successive inclusion of individuals until a dense discussion of the study's questions is possible. 
The sampling composition needs to be representative in order to deepen the thematic discussion ${ }^{(9)}$.

The hermeneutic-dialectical perspective was used in data analysis while the principles of the method of interpretation of meanings were used as a point of reference, which focused on interpretation of context, rationales and the logic of reports, actions, correlating data given the set of inter-relationships and conjunctures, among other analytical bodies ${ }^{(10)}$.

From this perspective, a comprehensive reading was carried out of the reports containing the transcription of interviews: regular and unique experiences were identified through the underlying meanings of ideas expressed during interviews. Finally, an interpretative synthesis was developed based on the confrontation of points of view and expressions of the actors' experiences. Considerations of the authors concerning the FHS professionals' interpretations were included in this synthesis, in a critical manner, to give more visibility to the meaning attributed to humanization as well as to difficulties and suggestions presented.

This study was approved by the City Health Department and the Ethics Committee regarding Research with Human Subjects at the Medical School of Marilia. The professionals were clarified regarding the purpose of the study and signed a free and informed consent form to participate.

\section{Results and Discussions}

As proposed, it was possible to identify core meanings regarding the understanding of FHS professionals concerning care humanization as well as difficulties faced and suggestions to improve care delivery.

\section{The Meaning of Humanization}

When the professionals from the FHS team attributed meanings to care humanization, they mentioned some aspects that are closely related to the principles and guidelines of the Single Health System (SUS), and which already convey relevant aspects of humanization in their propositions.

We highlight that the meaning of humanization in the set of reports of these professionals includes an enlarged view of users' health needs, respect for ethical principles and facilitated access to health services.

In the meanings obtained from the professionals' reports that indicate humanization as a enlarged view, the importance of considering the biopsychosocial aspects and context of people's lives is included, according to the following reports:

...I guess that care should not consider only the biological aspect, I always try to look to the human being, to the psychological and the social aspects of people... I try to establish bonds. P4

...the view you have of patients, not as a disease, but as a person, so this is the first step to apply humanization.P1

...we are accompanying these patients in the context of their lives. $\mathrm{CHA} 1$

Based on this extended view of the meaning of humanization, the results reveal that professionals consider the need for users to go beyond the disease and their bodies, drawing closer to an Enlarged Clinic, which proposes a transformation of individual and collective care, in order to enable individuals to be understood in their totality. The Enlarged Clinic deals with the uniqueness of each individual, without giving up the ontology of diseases and the possibilities of diagnosis and intervention ${ }^{(11)}$.

For the FHS team professionals, humanization of care also includes ethical aspects, such as respect for others, dignity, autonomy and putting oneself in another's place.

... it is about treating the person as a human being, with dignity, respect and it is what the orientation model of primary health proposes... N4

... respect; attention, seeing each family with their way of being, thinking, acting.... CHA4

... it is to sensitize the patient to his importance as protagonist in the recovery process. $\mathrm{P} 2$

... so I try to put myself in their place, as a patient, to tell them what I'd like to be told... NA4

Ethical principles are inseparable from the process of humanization in health care and mainly mean understanding each person in their uniqueness, creating conditions for them to exercise their autonomy. For that, one has to take into account values and experiences, preserving the human being's dignity ${ }^{(12)}$.

Based on this, one can infer that understanding is part of Humanization Policy due to the possibility of constructing "a new relational order, based on acknowledgment of one's otherness and on dialogue" (13).

According to the reports of the FHS professionals, facilitating access to health services and reducing waiting time are aspects that indicate humanized care according to what follows:

... humanized care is to reduce waiting time; to meet priorities according to the needs of each patient. D2

... when I schedule an appointment, for example, a $R X$ 
or a specialty, I try to schedule it at a facility close to the patient's house... the greatest difficulty they face is going to the service to get the exam's results; they don't have money for transportation... NA1

This aspect is focused by the NPH when it proposes, among its priorities, to address the difficulties patients have in accessing health services and consequences related to that issue.

Attributing these meanings to humanization of health care reveals that the interviewed professionals are consciously constructing new meanings for their practice. It is possible that this way of thinking can affect the proposal to change since the need for change has been already acknowledged.

\section{Difficulties for humanization}

It is possible to perceive in the health professionals' reports that the lack of professionals trained to act according to a new logic of care and excessive demand, coupled with difficulties related to the organization of the health services, are aspects that hinder the humanization of health care.

In regard to the lack of trained professionals to act in a humanized manner, the subjects indicate that current professionals do not have the required profile and are not sensitive.

I guess that most of the professionals are not sensitized to it... everyday you have to call their attention to this... M3

... the thing is that some professionals do not have the profile to work according to the program, you know... D4

The proposition to humanize health care also includes re-thinking the process of health professionals' education, which still carries a strong heritage of the traditional teaching model and technical approach. For that, educational practices should be organized in order meet the population's health needs within the routine of health units, trying to approximate academia and the health services in order to put SUS guidelines into effect(14).

Excess demand, which is considered an obstacle to humanize care is, according to the FHS interviewees, a result of a lack of health professionals, extra activities that are out of the professionals' scope and an excess of bureaucratic activities.

...today, here, our main difficulty is the lack of community health agents, they are the face of our service... because we loose bonds... it hinders the access of patients to the service... NA1

...so it's a large demand...we don't have to work only in homes, on the street; we also have to work here within the unit. $\mathrm{CHA} 4$
Actually, we get overloaded with paperwork; there're lots of things to take care of, and it's paper here and there. N3

When the professionals list these difficulties, they are suggesting that work processes in their daily practice are fragmented and bureaucratic, which in turn perpetuates a care model centered on curative actions, on complaints, contradicting the proposition of humanization.

In relation to aspects related to the organization of health services that hinder care humanization, the interviewees included limitation of access to secondary care, counter-reference deficiencies in addition to the lack of material and inappropriate physical space in the units.

... the main difficulty is in secondary care, because when patients leave here I don't hear from them anymore...NA1

...there is also a lack of specialists, we have deficiencies in many fields... P2

... there is a lack of material, sometimes we need procedures; like, sometimes, it gets out of our hands because we depend on other sectors... P1

... the unit here is too small...one auxiliary is collecting material in one room and the other room is occupied with some other professional... so you have to wait. NA3

The difficulties pointed out by the interviewed professionals are closely related to what is observed in the health services practice in relation to the implementation of the SUS principles as described in the Basic Document for the SUS Managers and Employees. This documents highlights, among other difficulties, a lack of complementarity between the basic network and the referral system; bureaucratization and vertica management of the health system; low investment in the education of workers; and that professional education does not meet the requirements of the current health policy ${ }^{(4)}$.

These difficulties limit the delivery of humanized health care. The glaring deficiency of access to specialized services, in addition to overloading the primary health care system because users have to constantly return to the unit, wears out trust in professionals who have to respond to users face-to-face.

This limitation of personnel coupled with a lack of material resources creates unfavorable working conditions, which in turn contributes to professional relationships that lack mutual respect, generating a fragmented and, consequently, dehumanized care(15).

\section{Suggestions to improve humanization conditions}

The professionals from the FHS team make suggestions that in general target the difficulties found 
in their routines, highlighting among them the proposal to educate and qualify professionals according to SUS principles, assign activities according to the professionals' role and improve the organization of health services.

In relation to the proposal to train and qualify professionals according to the principles of humanization, ideas that are highlighted include the need to develop a Permanent Education program, provide professional qualification, especially at the point of hiring these individuals to work in the health services, and provide an education focused on humanized aspects of care. The following reports illustrate these ideas:

... Permanent Education in the unit....questioning, seeing their daily practice and then reflecting upon it to modify it in a more productive way... D4

...it's education you know... so they already have a humanized education, something that people didn't have some time ago...N1

...they [the professionals] could be more trained, emphasis is not on humanization, it's seen as a matter of technical preparation... D3

The need to train and qualify health professionals to work according to the SUS principles has been acknowledged and different ministerial initiatives have been implemented. The following are examples of such initiatives: programs to foment changes in the undergraduate medicine programs (PROMED) and more recently Pro-Health for the nursing, medical and dentistry fields and the Education Program for Health at Work (PET-Saúde), in addition to supporting the education of specialists and residents, especially in family health, and the Permanent Education policy.

The team's professionals also proposed to define adequate roles since they end up performing activities that are not their responsibility. The following reports indicate these aspects:

... the community agent has to perform his work, which is with the families, on the street, in homes, in everyday routine...CHA2

... a secretary to help me out with these bureaucratic tasks so that I would have more time to provide humanized care... N3

The need for records to maintain order and control production diverts, to some extent, health professionals from their care role.

Finally, the reports of health professionals suggest the need to improve humanization conditions and better organize the health services. It is necessary for managers to recognize the real needs of services and modify the structure of units and the number of professionals to meet their needs.

I guess that the managing team... needs to know the unit, to know the demand, so that they have some notion of how the daily routine is here... NA4

In relation to the physical space... with little noise, appropriate temperature, a place that is not so small... N4

... more employees, because sometimes people have to wait longer downstairs in order to be cared for... CHA 3

Although the existence of possibilities to improve humanization conditions are acknowledged, it is necessary to consider the multiple interfaces this process represents, beginning with the necessary political/financial effort, permeating understanding and the desires of health services managers and culminating in the health professionals' daily practice.

Although the process requires co-responsibility of all those involved, the professionals who compose the FHS team are those who need to find the necessary strength to enable changes since it is in the relationship between these professionals and users that the desired transformation of practices occur.

\section{Final Considerations}

The challenge of implementing humanized practices in the primary care context involves complex issues that imply changes of posture for all those involved in the process, including professionals who work directly with health care, managers, policymakers and educational institutions ${ }^{(16)}$. From this perspective, the results of this study show that the professionals from the FHS understand that humanized health care means to have an enlarged view concerning the needs of patients, to act according to ethical principles such as respect for others, dignity and autonomy, and also facilitate access to health services and reduce waiting time. These aspects indicate an approximation of the meaning of humanization in the view of health professionals concerning the $\mathrm{NPH}$. Even though this situation has been acknowledged, when difficulties in the humanization process are indicated, what is observed is the perpetuation of fragmented and bureaucratic care that does not contribute to integrated and humanized actions.

The difficulties identified in the reports of the participants highlight the lack of prepared professionals, excessive demand and deficiencies in service organization. Educating and qualifying professionals according to the SUS principles is proposed, which means preparing these professionals to intervene in the context of services with a critical perspective aiming to transform such contexts; appropriate activities given professionals' roles; improve management and organization of services through structural support and qualified professionals; 
and enable the flow of care at the different levels of health care.

The conclusion is that moving toward the construction of an integrated and humanized model requires great effort and involves a deep process of reflection upon both the existent care model and the desired one.

\section{References}

1. Ministério da Saúde (BR). Secretaria de Assistência à saúde. Departametno de Atenção Básica. Política nacional de atenção básica. Brasília (DF): Ministério da Saúde; 2007. 61p.

2. Noronha AB. Graduação: é preciso mudar. Radis. 2002 dezembro; (5):9-16.

3. Santos Filho SB. Perspectivas da avaliação na Política Nacional de Humanização em Saúde: aspectos conceituais e metodológicos. Ciênc Saúde Colet. julho-agosto2007; 12(4):999-1010.

4. Ministério da Saúde (BR). Secretaria de Atenção à Saúde. Núcleo Técnico da Política Nacional de Humanização. Humaniza SUS: documento base para gestores e trabalhadores do SUS. Brasília (DF): Ministério da Saúde; 2006. 51p.

5. Simões ALA, Rodrigues FR, Tavares DMS, Rodrigues LR. Humanização na saúde: enfoque na atenção primária. Texto \& Contexto Enferm. julho-setembro 2007; 16(3):439-44.

6. Merhy EE. Saúde: cartografia do trabalho vivo. $2^{a}$ ed. São Paulo (SP): Hucitec; 2002. 189 p.

7. Backes DS, Koerich MS, Lorenzini A. Humanizing care through the valuation of the human being: resignification of values and principles by health professionals. Rev. Latino-Am. Enfermagem. 2007 janeiro-fevereiro; 15(1):34-41.

8. Feuerwerker LCM. Além do discurso de mudança na educação médica: processos e resultados. São Paulo (SP): Hucitec; 2002. 304 p.
9. Minayo MCS. O desafio do conhecimento: pesquisa qualitativa em saúde. 9a ed. São Paulo (SP): Hucitec; 2006. 406 p.

10. Gomes R, Souza ER, Minayo MCS, Malaquias JV, Silva CFR. Organização, processamento, análise e interpretação de dados: o desafio da triangulação. In: Minayo MCS, Assis SG, Souza ER, organizadores. Avaliação por triangulação de métodos: abordagem de programas sociais. Rio de Janeiro (RJ): Fiocruz; 2005. p. 185-221.

11. Campos GWS, Amaral MA. A clínica ampliada e compartilhada, a gestão democrática e redes de atenção como referenciais teórico-operacionais para a reforma do hospital. Ciênc Saúde Colet. julho-agosto2007; 12(4):849-59.

12. Fortes PAC. Ética, direitos dos usuários e políticas de humanização da atenção à saúde. Saúde Soc. setembrodezembro 2004;13(3):30-5.

13. Deslandes SF. Análise do discurso oficial sobre a humanização da assistência hospitlar. Ciênc Saúde Colet. 2004;9(1):7-14.

14. Bourget MMM. Programa Saúde da Família: guia para o planejamento local. São Paulo (SP): Martinari; 2005. 102 p.

15. Backes DS, Lunardi VL, Lunardi WD Filho. A humanização hospitalar como expressão ética. Rev. Latino-Am. Enfermagem. janeiro-fevereiro 2006; 14(1):132-5.

16. Oliveira BRG, Collet N, Viera CS. A humanização na assistência à saúde. Rev. Latino-Am. Enfermagem. março-abril 2006; 14(2):277-84. 